\title{
Susi Magdalena,
}

Department of Russian language, Faculty of Humanities,

Padjadjaran University (Bandung, Indonesia),

machdalena@unpad.ac.id

\section{Dr. Tajudin Nur,}

Professor, Department of Arabic, Faculty of Humanities,

Padjadjaran University (Bandung, Indonesia),

tajudin.nur@unpad.ac.id

\section{«Mega mendung»: an ornamental motif of Cirebon batik Indonesia}

Indonesian batik (hand painting on fabric) was recognized by UNESCO as a masterpiece of the intangible heritage of humanity in 2009. There are many types and styles of batik, with its own technique, ornamental set, and color scheme. Batik often serves not only as a cultural symbol, but also as an ethnoregional marker that defines the identity of Indonesian peoples. One of the centers of batik production is the city of Cirebon, the «gate of Central Java», that separates the center of the island from its western part. The most famous ornamental motif of Cirebon batik is the mega mendung, or sky-cloud ornament, which has a strong influence of Chinese culture. In Chinese mythology, the sky is a symbol of divinity, freedom, and greatness. The mega mendung motif represents a multi-layered sky. Traditionally, it has seven levels (layers), represented by different colors: from light and bright to dark. The favorite colors of a mega mendung are blue and dark red. Associated with masculinity and dynamism, these colors reflect the character of the coastal inhabitants (Cirebon is located on the coast of the Java sea) - they are open, active, adaptable, fun and happy people.

Keywords: batik; UNESCO intangible heritage; Cirebon; Jawa; Mega mendung motif; fabric painting; Indonesian culture; ornament; cultural symbol; ethnic marker; Javanese

\section{Символика цвета в тебризской миниатюре}

Отталкиваясь от исследований роли ивета в жизни человека, его влияния на все сферы жизнедеятельности, формирования мировоззрения и культурного кода, воздействия цвета на психику, быт, творческий процесс с точки зрения науки, автор рассматривает символику цвета в тебризской книжной миниатюре.

Ключевые слова: ивет, символика цвета, тебризская миниатюра, культурный код, средневековая каллиграфия, физиология ивета, восприятие ивета, искусство книги, наследие.

\section{Мир-Багирзаде Самира}

Алтай кызы

кандидат филологических наую

доцент, ведущий научный

сотрудник отдела

«Культурология»

Национальной академии наук

Азербайджана (Баку),

samiramb777@mail.ru
Значение цвета в жизни человека трудно переоценить. В течение всей жизни от рождения до смерти человечество пребывает в мире цвета, его гармонии и красоты. Окружающая его природа, климат с его цветовой гаммой воздействуют не только на образ жизни, менталитет, но и на психику, определяя характер, настроение и даже цель жизненных интересов. Краски природы - важнейший фактор в формировании культурного кода народа и страны. Природные цвета отражаются во всех творениях человека: коврах, картинах, керамике, декоративно-прикладном искусстве, костюме. Например, апшеронские ковры Азербайджана отражают всю природную колористику этого края: синий - цвет моря, голубой - цвет неба, светло-коричневый - цвет морского песка, желтый - цвет инжира, красный - цвет граната. 
Северный климат с его холодными красками формирует особую психологию человека - такие качества, как спокойствие, уравновешенность, хладнокровие; яркие краски южного климата дарят яркие әмоции. В прошлом путешественники-полярники описывали чувства тоски и подавленности, которые внушает сумеречная монотонность полярной пустыни с ее бесконечным простором, лишенным разнообразия цвета, теней и бликов. Цвет может вызвать бодрость или, наоборот, угнетенность и печаль. Многие исследователи отмечали своеобразный характер психологического воздействия каждого из цветов. В своей работе «Paint power ... and How to sell it» Л. Кент [11] описывает воздействие цветов на физиологию и психологию человека:

«Красный ивет - цвет огня и крови, цвет, вызывающий тепло, и его излучение, соседнее с инфракрасным, глубоко проникает в человеческие ткани. Красный цвет увеличивает мускульное напряжение и, следовательно, кровяное давление и ритм дыхания. Красный цветцвет жизненности и действия, он имеет большое влияние на настроение людей в этом направлении, он также стимулирует мозг и вызывает эмоциональные реакции, эффективен при меланхолии.

Оранжевый- пылкий, яркий и блестящий. Поскольку он одновременно и согревающий, и стимулирующий, то он может в разных случаях успокаивать и раздражать. Вызывает радость.

Желтый - солнечный цвет хорошего настроения и веселья. Психологические опыты показали, что это самый веселый цвет. Центр наибольшей светимости в спектре, стимулирующий зрение. Различные тона желтого цвета имеют, по-видимому, некоторую способность успокаивать слишком нервное, перевозбужденное состояние людей. Әтот цвет используется для лечения невроза.
Зеленый - цвет успокаивающий, цвет природы. Свежий и влажный, он дает некоторый отдых уму. Зеленый используют для лечения истерии и нервного переутомления. Пробуждает терпение. Уменьшает слишком яркое солнечное освещение.

Голубой обычно ассоциируется с небом или водой. Он светлый, прозрачный, холодный, успокаивающий. Его трудно сконцентрировать в небольшом пространстве. Под влиянием голубого цвета мускульное напряжение падает. В области чувств голубой напоминает о мире и пробуждает размышления. Наиболее любимый людьми цвет.

Фиолетовый - благородный, аристократичный цвет, вызывающий печаль.

Коричневый успокаивает, но вызывает депрессию, если его слишком много, чтобы избежать этого, его сочетают с желтым и оранжевым.

Черный - если употребляется один, угнетает. Очень полезен для создания контрастов.

Белый - символ чистоты, цвет холодный, если не сочетается с красным, желтым и оранжевым» [11, р. 6970; 1, с. 184].

Данная характеристика воздействия цвета на организм помогает архитекторам, дизайнерам, модельерам грамотно использовать цвета для комфортной и уютной жизни, врачам и психологам - преодолевать недуги и психологические проблемы пациентов. Например, белый цвет в архитектуре увеличивает пространство, но абсолютный белый монохром вызывает ощущение отсутствия пространства, состояние невесомости - он схож с облаками. Голубой цвет оказывает любопытное психологическое воздействие, максимально увеличивая пространство и создавая ощущение холода. Зеленый «цвет физического равновесия», он отражает внешний растительный мир, в котором человечество родилось и в котором оно желает жить. 
Различают холодные и теплые цвета: теплыми обычно называют красный, оранжевый, желтый, холоднъми - голубой, зеленый и фиолетовый.

Воздействие цвета на человека, его здоровье, психику, эстетику, образ жизни и сознание интересовало многих представителей науки и искусства, включая живописцев, архитекторов, дизайнеров, музыкантов, литераторов, поэтов. На протяжении столетий философы, физики, искусствоведы, археологи, этнографы, архитекторы, инженеры, врачи, физиологи, психологи обращались к проблеме цвета (и света), пытаясь их решать по-своему. Среди них - Аристотель, Насир ад-Дин (Насирэддин) Туси, Садиг бек Афшар, Леонардо да Винчи, М.В. Ломоносов и др. В трактатах Насир адДина ат-Туси, Омара Хайяма, ал-Каши, ал-Хорезми, АльФаргани отражены представления о величине, форме и изете предметов. Перу Насир ад-Дина Туси принадлежат трактаты «Об отражении и преломлении света», «Об изучении радуги»- исследуется преломление света и образование радуги, в его «Книге о драгоценных камнях» (Джавахир-наме) приводятся эталонные цвета камней.

Один из удивительных образцов восточной культуры книжная миниатюра, объединяющая четыре сферы художественного творчества: каллиграфию, искусство миниатюры, орнаментально-декоративное искусство и переплетное дело. Восточная миниатюра дает плоскостное видение изображаемого и носит декоративный характер, где важной особенностью является тонкое колористическое решение не только в самом рисунке, но и в оформлении каждой страницы. В Хое, Мераге и Тебризе создавались ранние образцы книжной миниатюры народов Ближнего и Среднего Востока. В конце XIII - начале XIV в. Тебриз (резиденция первых ильханов) и Мераге стали одними из наиболее развитых куль- турных центров мусульманского Востока. Азербайджанская миниатюра характеризовалась разнообразием различных техник и методов школ-миниатюр.

В пригородах Тебриза Газнийе и Рашидийе в начале XIV в. располагались учебные и научные учреждения, обширные библиотеки и художественные мастерские. В мастерских работали лучшие каллиграфы, художники и другие мастера книжного искусства, прибывшие сюда из разных стран Востока. Они переписывали и иллюстрировали книги-рукописи, в том числе капитальный труд «Джами ат-таварих» («Сборник летописей») Рашид ад-Дина -врача, историка и государственного деятеля.

Азербайджанские художники создали многочисленные иллюстрации к произведениям классической восточной поэзии: «Шах-наме» Фирдоуси и «Хамсе»Низами, произведения Саади и Хафиза, Джами и Навои, Хосрова Дехлеви, а также великолепные миниатюры на отдельных листах, собранные в специальные альбомы - «Муракка», свидетельствующие о том, что азербайджанская миниатюра прошла длительный и сложный путь развития, прежде чем достигла высшего расцвета в 1530-е годы.

В приведенной табл. 1 по материалам А.Ю. Казиева, изложенным в его исследовании записей Мирзы Сангшаха в книге «Художественное оформление азербайджанской рукописной книги XIII-XVII вв.», каллиграфы и миниатюристы обладали не только высоким графическим мастерством, но и тонким колористическим чутьем [2, с. 80-81].

Мастера орнаментального искусства - каллиграфы, нередко вступая в творческое содружество со строителями, создавали проекты декоративных надписей дворцовых и культовых сооружений. Наивысший расцвет искусство каллиграфии в Азербайджане достигло в XVI в. Каллиграфами были и правители (шах Исмаил I, шах 
Таблича 1. Колористическое решение миниатюры тебризской иколы (по материалам А.Ю. Казиева [2])

\begin{tabular}{|c|c|c|}
\hline Цвет бумаги & $\begin{array}{l}\text { Цвет чернил текста } \\
\text { (материал) }\end{array}$ & Имя каллиграфа \\
\hline Желтая & Красные (киноварь) & $\begin{array}{l}\text { Мир-Али Тебризи (XIV- } \\
\text { XV вв.) }\end{array}$ \\
\hline Желтоватая & Зеленые (ярь-медянка) & $\begin{array}{l}\text { Али-Риза Тебризи (XVI- } \\
\text { XVII вв.) }\end{array}$ \\
\hline Желтоватая & $\begin{array}{l}\text { Тона цветка персикового } \\
\text { дерева }\end{array}$ & Ала-бек Тебризи (XVI в.) \\
\hline Оранжевая & Темно-синие (лазурь) & $\begin{array}{l}\text { Мир-Абдуллах Тебризи } \\
\text { (XV в.) }\end{array}$ \\
\hline Оранжевая & $\begin{array}{l}\text { Голубые (лазурь } \\
\text { и белила) }\end{array}$ & $\begin{array}{l}\text { Абд ул-Баги Тебризи } \\
\text { (XVI-XVII вв.) }\end{array}$ \\
\hline $\begin{array}{l}\text { Ханайи (чайного } \\
\text { цвета) }\end{array}$ & $\begin{array}{l}\text { Тона цветка персикового } \\
\text { дерева }\end{array}$ & Али-Риза Тебризи \\
\hline Розовая & Черные (сажа) & Мир-Абдуллах Тебризи \\
\hline Розовая & Зеленые (ярь-медянка) & Абд ул-Баги Тебризи \\
\hline Голубая & $\begin{array}{l}\text { Розовые (киноварь } \\
\text { и белила) }\end{array}$ & Мир-Абдуллах Тебризи \\
\hline Голубая & $\begin{array}{l}\text { Белые (свинцовые } \\
\text { белила) }\end{array}$ & Али-Риза Тебризи \\
\hline Голубая & $\begin{array}{l}\text { Розовые (киноварь } \\
\text { и белила) }\end{array}$ & Али-Риза Тебризи \\
\hline Голубая & $\begin{array}{l}\text { Розовые (киноварь } \\
\text { и белила) }\end{array}$ & Ала-бек Тебризи \\
\hline Лазурная & $\begin{array}{l}\text { Золотые (жидкое } \\
\text { золото) }\end{array}$ & Мир-Абдуллах Тебризи \\
\hline Лазурная & $\begin{array}{l}\text { Золотисто-желтые } \\
\text { (сернистый мышьяк) }\end{array}$ & Ала-бек Тебризи \\
\hline
\end{tabular}

Окончание табл. 1

\begin{tabular}{|l|l|l|}
\hline Цвет бумаги & $\begin{array}{l}\text { Цвет чернил текста } \\
\text { (материал) }\end{array}$ & Имя каллиграфа \\
\hline $\begin{array}{l}\text { Лазурная } \\
\text { гляневая }\end{array}$ & $\begin{array}{l}\text { Золотые (жидкое } \\
\text { золото) }\end{array}$ & Азхар Тебризи \\
\hline Зеленая & Черные (сажа) & Джафар Тебризи (XV в.) \\
\hline Фисташковая & Красные (киноварь) & Мир-Абдуллах Тебризи \\
\hline Белая & Зеленые (ярь-медянка) & Мир-Али Тебризи \\
\hline Белая & $\begin{array}{l}\text { Шафраново-коричневые } \\
\text { (хна и сажа) }\end{array}$ & Абд ул-Баги Тебризи \\
\hline Белая & Синие (лазурь) & Абд ул-Баги Тебризи \\
\hline Черная & $\begin{array}{l}\text { Золотые (жидкое } \\
\text { золото) }\end{array}$ & Неизвестный автор \\
\hline
\end{tabular}

Тахмасиб I). Нередко каллиграфы были также и поэтами, и художниками, и резчиками, оформляли миниатюры и книги (Садиг бек Афшари, Али Рза Аббаси Тебризи), работали по металлу и создавали архитектурный декор.

На Среднем Востоке наиболее ранние образцы азербайджанской миниатюры, иллюстрирующие «Варга и Гюльшах» (начало XIII в., музей Топкапы, Стамбул, художник Абдул Момин ибн Мухаммед аль-Хойи), «Манафи аль-Хайван» (1298 г.), «Джами ат-таварих» (1308, 1314 гг.), свидетельствуют о возникновении новой школы.

В силу своего географического положения Азербайджан был перекрестком культур Запада, Востока, Севера и Юга. В формировании и первоначальном развитии художественного стиля тебризской школы миниатюры переплетались традиции различных школ: Восточного Туркестана - посредством китайских и уйгурских 
художников, привезенных в Тебриз монгольскими ильханами, и арабо-месопотамской живописи через багдадскую школу.

Азербайджанский художник, поэт, каллиграф, музыковед Садиг бей Афшар или Садиги (1533, Тебриз - 1610, Исфаган) написал трактат о живописи «Ганун ос-совар» [7]. Этот труд - свидетельство длительного развития традиции тебризской миниатюры, повлиявшей и на другие школы изобразительного и декоративного искусства не только Востока, но и Запада. Культура арабского ислама обогащается различными традициями Востока: китайской, монгольской, иранской, египетской, турецкой, азербайджанской и др. Читатели «Ганун ос-совар» получали полное представление об искусстве книжной миниатюры и ее связи с другими искусствами исламского средневекового Востока: каллиграфией, изобразительным искусством, архитектурой, декоративно-прикладным искусством, поэзией, музыкой. Автор раскрывает символику и философский смысл декоративных мотивов, связь изображаемого с литературным содержанием. Элемент орнамента, цвет, рисунок, слово указывают на определенную традицию, по которой можно узнать школу, мастера и саму идею творческого произведения. Автор дает развернутую колористическую характеристику, предлагает свое видение гармоничных и дисгармоничных цветовых решений, причем делает это в особой стихотворной форме - масневи:

\section{1. Некоторое время гуламом}

покорным я служил у него. (Садиги пишет, что находился в услужении у великого художника Музаффара Али. - Прим. С.М.)

32. Путь изобразительства настолько я прошел,

ито от формы к смыслу дорогу нашел.

33. Как славное имя того стариа-наставителя, Сталя по бедителем странъ этого искусства. (игра слов, «Музаф- фар» переводится как победитель, тем самым Садиги раскрывает здесь имя своего учителя. - Прим. С. М.)

34. Милостью Всевыннего, чтоб бъла радостна его душа,

Да будет озарена полная отваги его душа!

35. Да будет (он) избавлен от мирских грехов

И погружен в милость вечного блаженства [7, с. 68-69].

В разделе «О смешении красок и технике письма» Садиги рекомендует использовать чистые краски, при смешении их не брать те, что образуют новый цвет. Садиги предпочитал два технических приема: 1) дам шуй - «работа кончиком кисти», прием использовался при выполнении узора, подобного цветку фруктового дерева, деталь изображения растушевывалась, создавая постепенный переход от темного цвета к светлому; 2) мияншу - «работа талией кисти», прием использовался при ровной сплошной заливке фона и крупных деталей. Далее мастер лакировал окрашенное основание для последующей отделки жидким золотом [7, с. 81-82].

На средневековом Востоке, как и во времена античности, музыка представляла собой единство поэзии и мелодии. Сохранились сведения о средневековых музыкантах-поэтах, песенных жанрах (мерсия, маратхи, уруджуза, хиджа, медхия) и музыкальных инструментах

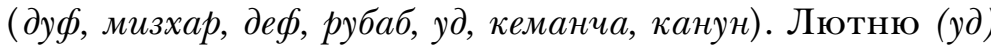
завезли в Европу именно арабы. Каждая струна лютни связывается с определенным темпераментом (по Гиппократу) и цветом: зир (верхний регистр, высокий звук) - холерик и желтый цвет; масна (верхний регистр) - сангвиник и красный; мислас (нижний регистр) - флегматик и белый; бам (нижний регистр, низкий звук) - меланхолик и черный. К этим четырем струнам - телу музыки - добавляется пятая - струна души. Спустя столетия Н.А. Римский-Корсаков и А.Н. Скрябин дали цветовую характеристику каждому звуку и тональности. Явление музыкально-звуко- 
вой синтезии - разновидность хромәстезии (цветового слуха). Скрябин также написал симфоническую поэму «Прометей (Поэма огня)» со специальной исполнительской строкой «Luce» (свет), которая исполнялась с использованием светомузыки и цветового спектра.

Идея гармонии пронизывала всю мусульманскую культуру средневековья, которая отражала основные положения Корана.

Широкое развитие в средневековой поэзии получил дескриптивный жанр васф, основанный на принципе восточного сравнения - уподобления одних явлений другим, в форме нанизываемых один за другим усложненных образов-метафор, нередко тяготевшие к зрительному, конкретно-чувственному образу. Поэтические описания живописны, декоративны, проникнуты орнаментальным видением. Лик земли открывается взору поэта как лента, узор, драгоценность. Характерен образ прекрасного покрывала, роскошной ткани, богатого плаща, узорчатого ковра. Поэты воспевают сад, как пестротканую одежду, рощи, расписанные золотом. Деревья, плоды, птицы, созвездия сравниваются с драгоценными каменьями, искусные руки ветров рисуют на текучей воде узоры из пузырьков воды. Поэты используют образы самоцветов, благородных металлов, вышивок: ручей - сияющий на солнце обнаженный меч, месяц - серебряный браслет, рябь на воде сравнивается с кольчугой, с посеребренной, покрытой резьбой колонной, в наступающей ночи река становится синим ковром, расшитым золотом. С узорчатостью предметов сочетается их светозарность. Этим качеством часто наделяются изображения дворца, правителя, прекрасной женщины.

Не касаясь стилистики классической арабской поэзии с ее тягой к эстетизации и усложнению чисто словесного образа, упомянем лишь насыщенную красочную палитру стихов, где явление и предмет наделены конкретным, но поэтически преображенным цветом. Через ощущение цвета ассоциативный образ получает подчас зримую картинность. Если предста вить себе художественное наследие арабского мира как цельную художественную систему, в составе которой искусство слова, архитектура, музыка, орнамент, каллиграфия, то приходится признать, что все эти виды объединялись общим характером поэтики, тяготеющей к формам условной выразительности.

Искусство книжной миниатюры, как и декоративноприкладное искусство, архитектура, каллиграфия, музыка Востока, представляет собой ценный и значимый памятник историко-культурного наследия со своими исторически сложившимися канонами, ценностями и религиозно-мистическими представлениями.

Михаил Васильевич Ломоносов в своем «Слове о происхождении света, новой теории о представляющих цветах» высказал мысль о трехцветовой основе зрения. Сегодня уже можно сказать, что цвет воспринимается человеком разносторонне, не только одним зрением, но и с участием всех чувств, включая слух, осязание, обоняние, вкус. Например, желто-лимонного цвета конфета со вкусом мяты может вызвать недоумение и удивление, черная роза - неприятие, разноцветное освещение аппетитной пищи может вызвать отвращение к ней. Многие ученые пришли к выводу о возможности борьбы с шумом с помощью цвета.

Своя символика цвета была в театральной традиции античности, Японии и Китая. Так, цвет и форма масок китайской оперы указывает на титул, характер, добродетели и пороки персонажа: красный цвет означает храбрость, мужество, целостность; черный - неискрен- 
ность и резкость, в то же время дьявол появляется в красном, черном и зеленом.

Цвета используются как важные и необходимые символы, применяемые в дорожном движении в указателях, знаках и светофорах.

Особую роль цвет играет в геральдике. Азербайджанский флаг сочетает синий, зеленый и красный цвета. Идею флага Азербайджанской Демократической Республики (и нынешнего Азербайджана) предложил Алибей Гусейнзаде (1864-1940) - ученый, философ, художник и врач, написавший в соавторстве «Энциклопедический медицинский словарь». В основе идеи флага лежало триединство: тюркизаиия - синий цвет полосы флага; исламизаиия - зеленый цвет полосы флага; европе изация и идеи модернизаиии европейской культуры, в основе которой лежат идеи французского просветительства, заимствованные у просветителей исламской цивилизации, которые в Средние века дали возможность прогрессивному развитию науки и просвещения в медресеуниверситетах, делая открытия во всех областях науки и рассматривая науку как целостное явление, изучая все отрасли ее как единый организм, мусульманские просветители средневековья обладали энциклопедическими знаниями, а также создали огромное количество словарей, энциклопедий, трактатов во всех сферах науки и искусства. Красный цвет флага символизирует также свободу, просвещение и развитие общества.

Идея триединства Али Гусейнзаде нашла продолжении в творчестве Ахмеда Агаоглу (Агаев) и других просветителей того времени. В 1919-1920 гг. Ахмед Агаев написал труд Uc Medeшyet («Три культуры») [9], опубликованный в 1927 г. В нем он сравнил западную культуру/цивилизацию с буддийской и исламской и указал на превосходство первой. В «Трех культурах» он настаи- вал на принятии западных ценностей не только путем ношения западной одежды или открытия учреждений западного типа, но своим мышлением, сердцем, взглядами и восприятием [8, р. 13]. Одними из основных свойств западной цивилизации Агаоглу считал либерализм и свободу личности. В противоположность восточным цивилизациям, по его мнению, на Западе развитие индивидуума является основой развития общества [9, р. 862.].

Завершая исследование, хотелось привести аят - послание Всевышнего из Корана - религии о разнообразии и многоцветии всего сущего на земле: «Так и среди людей, скота, животных / Встречаются различные ивета... / Аллах поистине могуч...» (Коран, 35:28) [3, с. 460].

\section{Лumepamypa:}

1. Деррибере М. Цвет в деятельности человека / сокр. пер. с фр. А.М. Григорьева; предисл. А. Щипанова. М.: Стройиздат, 1964. 183 с.

2. Казиев А.Ю. Художественное оформление азербайджанской рукописной книги XIII-XVII веков. М.: Книга, 1977. 357 с.

3. Коран. Перевод смыслов и комментарии Иман Валерии Пороховой. М.: РиполКлассик, 2016. 800 с.

4. Мир-Багирзаде С.А. Исламское искусство (Коран и искусство). Баку, 2009. 124 с.

5. Мир-Багирзаде С.А. Очерки по теории и истории культуры. Баку, 2019. 272 с.

6. Насирэддин Туси М. Джавахир-наме: [Трактат, посвящ. описанию драгоцен. камней. Пер. с фарси / Насирэддин Туси. Баку: Элм, 1984. 31 с.

7. Садиг-бек Афшар. Ганун ӧс-сӧвӓр: (Трактат о живописи): [Перс. текст и пер.] Введ., [с. 13-64], пер., коммент. и примеч. доц. А.Ю. Казиева; Акад. наук АзССР, Ин-т архитектуры и искусства. Баку: Изд-во Акад. наук АзССР, 1963. 101 с.

8. Agayef A. Türk Alemi / Türk Yurdu. 1328. I/10.

9. Agaoglu A. Üc Medeniyet. Istanbul: Doğu Kitabevi, 2013.

10. Haciyev A. R ng $n$ z riyyasının sasları. Bakı: Elml r Akademiyası, 1951.

11. Kent L. Paint Power ... and How to sell it. National Paint, Varnish \& Lacquer Assn. 1947. $350 \mathrm{p}$. 


\section{Samira Altai kizi Mir-Bagirzade,}

PhD, Associate Professor, Leading researcher,

Department of Cultural studies,

National Academy of Sciences of Azerbaijan (Baku),

samiramb777@mail.ru

\section{Symbolism of colors in the Tabriz miniature}

The author examines the symbolism of color in the Tabriz book miniature by reference to research into the role of color in human life, its influence on all spheres of life, the formation of worldview and cultural code, the impact of color on the psyche, life, and creative process from the point of view of science.

Keywords: color; color symbolism; Tabriz miniature; cultural code; medieval calligraphy; color physiology; color perception; book art; heritage

\section{Глеб Унукаев}

10.37492/ETN0.2020.62.4.015

\section{Феномен фэнтези в контексте социальных сетей (на примере «Саги о Ведьмаке»)}

На примере «Саги о Ведьмаке» польского фантаста Анджея Сапковского и продуктов массовой культуры, созданных на ее основе, автор анализирует феномен фэнтези в контексте социальных сетей. На основе контент-анализа социальной сети ВКонтакте были выявлены характерные черты объединения пользователей в рамках культуры фэнтези и основные формы активностей пользователей, интересующихся «Сагой о Ведьмаке».

Ключевые слова: феномен фэнтези, культура фэнтези, «Сага о Ведьмаке», Сапковский, социальные сети, рунет, ВКонтакте.

Популярный жанр фэнтези имеет множество адептов по всему миру и продолжает завоевывать новых по-

Унукаев Глеб Андреевич, магистрант кафедры культурологии ИСГО мПгу (Москва),zzogark@gmail.com читателей, покорив области литературы, кино, компьютерных игр, проникнув в Интернет и социальные сети. Чтобы убедиться в этом, достаточно проследить за динамикой прироста подписчиков на онлайн-сервисах после выхода фэнтези-сериалов (Netflix), проанализировать статистику игроков в The Witcher 3: Wild Hunt. Продукты жанра фэнтези, в свою очередь, обрастают комьюнити, каждый сеттинг (среда, в которой происходит действие) собирает немало сторонников, объединенных общим предметом увлечения. Әто имеет отклик в социальных сетях, которые служат доминирующим инструментом для консолидации и коммуникации людей. Данные обстоятельства вызывают необходимость их понимания и анализа, который есть смысл проводить в контексте конкретного фәнтези-продукта. Каждый из них имеет свою обособленную аудиторию, но подчиняется одним и тем же законам жанра и объединяет людей в определенном векторе. Рассмотрим актуальность жанра фэнтези в социальных сетях на примере «Саги о Ведьмаке» Анджея Сапковского, которая является ярким представителем данного феномена культуры, а также имеет колоссальное количество фанатов.

Необходимо упомянуть, что фэнтези - в первую очередь литературный жанр [2], в котором описываемые события происходят в мирах, наполненных магией, необычными животными и существами, а эстетика образов главных героев и их оружие вдохновлены средневековьем. Зародившись в литературе, жанр становится частью массовой культуры и в настоящее время представлен и в кино, и в сфере компьютерных игр, и в живописи, и в музыке.

Первую книгу о Ведьмаке Геральте из Ривии - «Последнее желание» - польский писатель Анджей Сапковский (род. В 1948) выпустил в 1991 году. История главного героя Геральта получила продолжение. Последняя книга саги опубликована в 2013-м [3], однако широкую популярность вселенная Ведьмака обрела отнюдь 